\title{
Mycobacterium malmoense pulmonary infection in France: a case report
}

\author{
Simon Grandjean Lapierre, Mustapha Fellag, Célia Magan and Michel Drancourt * (1)
}

\begin{abstract}
Background: Mycobacterium malmoense infections have frequently been reported in northern Europe since the late 1970s. Factors accounting for this geographically localized epidemiology remain poorly understood.

Case presentation: We report the case of a 54-year old man concomitantly diagnosed with non-small cell lung carcinoma and $M$. malmoense pulmonary infection. We present detailed clinical, microbiological and radiological elements strongly arguing for $M$. malmoense true pathogenicity. Since $M$. malmoense infection has rarely been reported in France, we also provide elements of the epidemiological investigation and a literature review of potential acquisition and transmission pathways of M. malmoense. We detail therapeutic interventions and subsequent favorable evolution.
\end{abstract}

Conclusion: Mycobacterium malmoense is a recognized respiratory pathogen for which routes of infection need to be better investigated.

Keywords: Mycobacterium malmoense, Non-tuberculous mycobacteria

\section{Background}

Twenty years ago, the non-tuberculous mycobacterium Mycobacterium malmoense was described as a new species after being isolated from the respiratory secretions of four patients with pulmonary infections in the city of Malmö, Sweden [1]. Since then, very few cases were reported outside this endemic region. Cumulative reporting of M. malmoense infection cases allowed the recognition of two distinct associated clinical syndromes, namely pediatric isolated lymphadenitis and adult tuberculouslike pulmonary infection. Pulmonary infections most frequently occur among long-time smoking patients with chronic obstructive pulmonary disease but acute invasive or disseminated presentation may be seen in the context of significant immunosuppressive conditions such as hematologic malignancy and HIV [2, 3]. Atypical cases of septic arthritis, mycotic aneurysm and post-operative surgical site infection have also been reported [4-6]. As seen with other mycobacterial species, concomitant or

*Correspondence: michel.drancourt@univ-amu.fr

Aix-Marseille Université, URMITE, UMR CNRS 7278, IRD 198, INSERM

1095-IHU Méditerranée Infection, 19-21 Boulevard Jean Moulin,

13005 Marseille, France subsequent Aspergillus spp. infection of pre-existent or mycobacterial disease induced pulmonary lesions may occur with M. malmoense [7].

Few cases of M. malmoense have been reported outside the endemic region and in particular, only eleven cases have been reported in patients living in France. We are reporting one more such case, questioning the sources of infection in this patient.

\section{Case presentation}

In 2016, a 54-year-old man was referred to our institution with a newly established diagnosis of non-small cell lung carcinoma. Clinical evaluation revealed chronic cough, appetite loss and cachexia. Prior to initial pulmonary bronchoscopy investigation, two consecutive tomodensitometry imaging studies had shown left hilar consolidation and right upper lobe cavitary lesions to be stable in time over a 1-year period. His past medical history included chronic obstructive pulmonary disease, chronic hepatitis $\mathrm{C}$, associated cryoglobulinemia and lymphoma for which he had received chemotherapy and cervical radiation therapy in 2003. He was a chronic alcohol, 
tobacco and cannabis drug user and took no regular medication.

Prior to chemotherapy initiation, mycobacterial culture performed on the initial diagnostic bronchoalveolar lavage revealed the presence of $M$. malmoense. During the following 3-month period, $M$. malmoense was repeatedly isolated from six sputum and bronchial aspiration control specimens. According to local procedures, isolates were recovered from BACTEC ${ }^{\mathrm{TM}}$ MGIT $^{\mathrm{TM}}$ (Becton-Dickinson, New Jersey, United States) radiometric mycobacterial broth culture system with incubation at $37{ }^{\circ} \mathrm{C}$ for an average of 25 days. Identification to the species level was confirmed by mass spectrometry and RNA polymerase $B$-subunit coding rpoB gene sequence analysis per local procedures $[8,9]$. The $r p o B$ sequence was 612-bp long and shared $99.8 \%$ similarity with M. malmoense ATCC 29671 strain (GenBank Accession No. GQ153314). The second closest mycobacterium species was Mycobacterium palustre sharing only 571/612-bp 93.3\% (GenBank Accession No. HM022210). Broth dilution antimicrobial susceptibility testing was performed per published Clinical Laboratory Standard Institute guidelines [10] and showed the isolate to be in vitro susceptible to rifampicin, clarithromycin, streptomycin and amikacin; and in vitro resistant to isoniazid, ethambutol, ofloxacin, doxycycline, tigecycline and linezolid.

Detailed epidemiologic and potential environmental exposure history revealed the patient had been incarcerated in France in 2016 and regularly ate both fox and squirrel bush meat. He reported having exceptionally eaten MukTuk, a traditional Inuit and Chukchi meal of frozen whale skin and sub-cutaneous adipose tissue and having been in close contacts with a friend and his dog upon their return from Scotland [11].

A treatment of isoniazid $5 \mathrm{mg} / \mathrm{kg} /$ day, rifampin $10 \mathrm{mg} /$ $\mathrm{kg} /$ day, ethambutol $15 \mathrm{~g} / \mathrm{kg} /$ day and clarithromycin $500 \mathrm{mg}$ bid was initiated to cover both tuberculosis and M. malmoense infection. On control imaging following both antimycobacterial treatment and chemotherapy initiation, superior lobes consolidated and cavitary lesions had regressed. Clinical evolution was also favorable. On the other hand, nodular and reticulonodular infiltrates in lower lobes were progressing. These discordant radiologic findings were interpreted as ongoing infection. Extended microbiologic workup was repeated but unrevealing except for an additional $M$. malmoense positive culture.

Upon submission of this paper, the patient was still alive, undergoing his chemotherapy treatments and receiving full antimycobacterial therapy without side effects.

\section{Discussion}

Mycobacterium malmoense infection has rarely been reported in France as only eleven such cases have been retrieved in our literature review [12-22]. We report on the twelfth case, firmly documented by the isolation of six different isolates from distinct and consecutive clinical samples collected from the patient here described. All the isolates have been identified with certainty using mass spectrometry and DNA sequencing in the presence of appropriate controls $[8,9]$. Moreover, $M$. malmoense had not previously been isolated in our laboratory and was not handled in our laboratory at the time specimens were obtained from the patient, rendering in-laboratory contamination not possible.

Mycobacterium malmoense was interpreted as being responsible for initial clinical and persistent radiological features in this patient and he therefore received appropriate antibiotic treatment [23]. In the context of cachexia, poor residual pulmonary function and imminent chemotherapy initiation, our patient was empirically treated with a combination of four effective drugs. M. malmoense in vitro antimycobacterial susceptibility testing results and in vivo treatment outcomes were frequently shown to have poor correlation [24]. In 1999, based on in vitro synergistic activity and prior case series clinical data, the British Thoracic Society recommended a 2-year rifampin and ethambutol therapy for M. malmoense pulmonary diseases and proposed the use of surgical resection as an adjunctive approach for unilateral disease in patients with poor tolerance or response to medical treatment [25]. In 2000, a randomized controlled trial was performed on 223 patients with non-tuberculous mycobacteria (NTM) pulmonary disease including 106 M. malmoense infections [26]. Patients were randomized as receiving a two-year course of rifampin and ethambutol alone or rifampin, ethambutol and isoniazid combination therapy. After up to a 5-year follow-up period, no difference was observed between groups on deaths and microbiological failures outcomes. Besides recommended first line antimycobacterial agents, macrolides and fluoroquinolone have occasionally been used in combination therapy with variable outcomes [27]. The most recent published guidelines on the treatment of non-tuberculous mycobacteria from the American Thoracic Society and the Infectious Disease Society of America reinstated these same recommendations [23].

A disproportionately high incidence of $M$. malmoense lymphadenitis and pulmonary infections in United Kingdom and Northern Europe was first reported in two case series of the 1980s [28, 29]. This epidemiologic trend was then confirmed by a large-scale 3-year retrospective study from 1990 to 1993 [30]. More than 25 years 
later, despite a wide distribution of accurate diagnostic tools and recognition of the species as a human pathogen, this geographic predominance persists (Fig. 1) [31]. In 2001, an epidemiologic investigation using restriction fragment length polymorphism molecular typing on 79 M. malmoense clinical isolates along with detailed patients' demographic data failed to demonstrate patient to patient transmission [32]. Another large-scale epidemiologic study reviewing every diagnosed case in northern United Kingdom between 2000 and 2005 was also unable to identify space-time clusters of cases [33]. Even in the context of documented strong epidemiologic link between two cases with smear-positive sputum, molecular epidemiology infirmed human to human transmission [34]. This geographic distribution of disease is still poorly understood but available data do not support human to human transmission or common environmental infection source.

Reported animal infection cases include disseminated and skin infections in cats in Finland and United Kingdom $[35,36]$ and lymph node infections of cattle Northern Ireland and Hungary $[37,38]$ and pork in Netherlands
[39]. These data and those from animal model experimental studies reveal that multiple mammal species are either vulnerable hosts or healthy carriers and therefore potential vectors of $M$. malmoense. Interestingly, animal and human reported cases have the same geographic distribution which could indicate a common environmental source or animal to human transmission. However, to our knowledge, human acquisition of $M$. malmoense from an animal or environmental source has never been reported either.

Mycobacterial host-adaptation has been correlated with potential ecological niches determinants such as immediate environment salt concentrations for other NTMs [40]. Environmental studies performed in Finland demonstrated that peatland soils and surface waters such as those from Scotland and the United Kingdom present optimal physico-chemical proprieties for the growth of M. malmoense among other NTMs [41, 42]. Our patient did not report being in contact with such environments on an exceptional or regular basis but clearly reported having been in contacts with a living animal and eating animal product from these geographic regions.

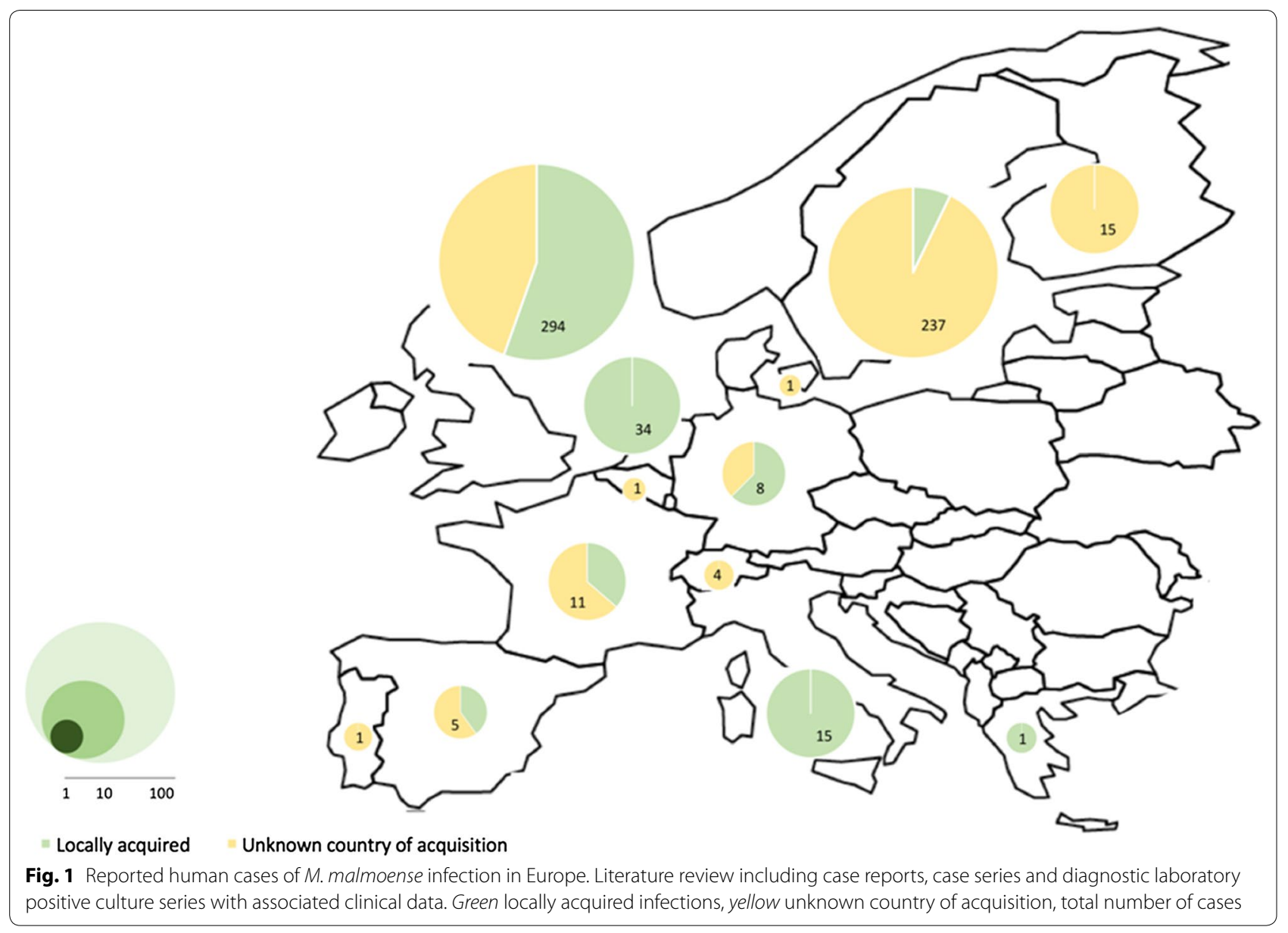




\section{Conclusion}

This case is highly interesting since it documents $M$. malmoense infection in a patient living in a low-incidence country where no environmental or animal isolates have been described. Whether infection was acquired through respiratory or digestive route and whether human to human or human to animal transmission occurred could not be established. Other case reports such as the one of a 53-year old Canadian woman with previously normal lung function but chronic intestinal inflammation due to Crohn's disease support the hypothesis of a digestive route of infection [43]. Moreover, M. malmoense has previously been isolated in human stools and this infection pathway is well documented for other mycobacterial species [43-45].

Epidemiology studies linking genetically identical human and environmental isolates in space and time are still needed to better understand $M$. malmoense routes of infection.

\section{Abbreviation}

NTM: non-tuberculous mycobacteria.

\begin{abstract}
Authors' contributions
All cited authors qualify for authorship according to the ICMJE guidelines. SGL was implicated in clinical care of the patient, reviewed patient's medical chart and microbiology data, performed literature review and was a major contribution in writing the manuscript. MF performed extended veterinary studies review and analysis. CM was implicated in chart review and microbiologic investigation. MD was implicated in clinical care of the patient, overviewed the microbiological analyses and was a minor contribution in writing the manuscript. All authors read and approved the final manuscript.
\end{abstract}

\section{Acknowledgements}

MF benefits from a Ph.D. Grant from Fondation Méditerranée Infection, Marseille, France.

\section{Competing interests}

The authors declare that they have no competing interests.

\section{Availability of data and materials}

Data supporting this manuscript are archived and protected in the personal patient medical chart and laboratory information systems at our institution.

\section{Consent for publication}

Written and signed consent to publish the information presented in this manuscript was obtained from the patient.

\section{Ethics approval and consent to participate}

The need for ethics approval was waived for this work (case report).

\section{Funding}

This work was supported by URMITE, IHU Méditerranée Infection, Marseille, France.

\section{Publisher's Note}

Springer Nature remains neutral with regard to jurisdictional claims in published maps and institutional affiliations.

Received: 9 May 2017 Accepted: 23 August 2017

Published online: 31 August 2017
References

1. Schroder $\mathrm{KH}$, Juhlin I. Mycobacterium malmoense so. nov. Int J Syst Evolut Microbiol. 1977;27(3):241-6.

2. Fakih M, Chapalamadugu S, Ricart A, Corriere N, Amsterdam D. Mycobacterium malmoense bacteremia in two AIDS patients. J Clin Microbiol. 1996;34(3):731-3.

3. Castor B, Juhlin I, Henriques B. Septic cutaneous lesions caused by Mycobacterium malmoense in a patient with hairy cell leukemia. Eur J Clin Microbiol Infect Dis. 1994;13(2):145-8.

4. Callaghan R, Allen M. Mycobacterium malmoense infection of the knee. Ann Rheum Dis. 2003;62(11):1047-8.

5. Brereton AS, El Teraifi H. Mycobacterium malmoense: dissemination causes a popliteal aneurysm in a 74-year-old man. BMJ Case Rep. 2012;2012:1220115471.

6. Dave J, Williams AT, Jenkins PA. Mycobacterium malmoense infection in an immunocompromised patient. J Infect. 1993;26(2):223-4.

7. Bollert FG, Sime PJ, MacNee W, Crompton GK. Pulmonary Mycobacterium malmoense and aspergillus infection: a fatal combination? Thorax. 1994;49(5):521-2.

8. Zingue D, Flaudrops C, Drancourt M. Direct matrix-assisted laser desorption ionisation time-of-flight mass spectrometry identification of mycobacteria from colonies. Eur J Clin Microbiol Infect Dis. 2016:35(12):1983-7.

9. Adekambi T, Colson P, Drancourt M. rpoB-based identification of nonpigmented and late-pigmenting rapidly growing mycobacteria. J Clin Microbiol. 2003;41(12):5699-708.

10. CLSI. Susceptibility testing of mycobacteria, nocardiae, and other aerobic actinomycetes; approved standard. 2nd ed; 2011.

11. Sheehy T, Roache C, Sharma S. Eating habits of a population undergoing a rapid dietary transition: portion sizes of traditional and non-traditional foods and beverages consumed by Inuit adults in Nunavut, Canada. Nutr J. 2013;12:70

12. Denis C, Saltiel JC, Choffel C, Baufine-Ducrocq H. Pulmonary infection caused by a rare mycobacterium, Mycobacterium malmoense. Revue des maladies respiratoires. 1987;4(3):133-5.

13. Doutre MS, Beylot C, Maugein J, Boisseau AM, Long P, Royer P, et al. Cutaneous infection caused by Mycobacterium malmoense in a patient with myelodysplastic syndrome. J R Soc Med. 1993;86(2):110-1.

14. Debieuvre D. Pulmonary Mycobacterium malmoense and Aspergillus infection. Thorax. 1995;50(2):216.

15. Schmoor P, Descamps V, Lebrun-Vignes B, Crickx B, Grossin M, Nouhouayi $A$, et al. Mycobacterium malmoense cutaneous infection in an immunocompetent patient. Ann Dermatol Venereol. 2001;128(2):139-40.

16. Job V, Lacaze O, Carricajo A, Fournel P, Vergnon JM. Medical-surgical treatment of pulmonary infection with Mycobacterium malmoense. Revue des maladies respiratoires. 2004;21(5 Pt 1):993-6.

17. Camara B, Borrel B, Panteix G, Merault JM, Vialas M, Sanchez A, et al. Infection due to Mycobacterium malmoense in an immunocompetent patient. Revue des maladies respiratoires. 2008;25(9):1127-30.

18. Guiot J, Ramaut M, Massart B, Louis R. Mycobacterium malmoense infection in an immunocompetent patient. Revue medicale de Liege. 2009;64(7-8):390-3.

19. Abgueguen P, Rabier V, Mahaza C, Warot A, Chennebault JM, Pichard E. Mycobacterium malmoense: an underestimated nontuberculous mycobacterium. Diagn Microbiol Infect Dis. 2010;66(1):98-100.

20. Gomez-Abreo D, Prost C, Couraud S, Parmeland L, Carret G, Boibieux A, et al. Chronic necrotizing pulmonary aspergillosis following an infection by Mycobacterium malmoense. Revue des maladies respiratoires. 2012;29(3):435-9.

21. Grammatico-Guillon L, Lanotte P, Bastides F, Veziris N, Bernard L, Rosset P. Voluminous pseudotumor due to Mycobacterium malmoense. La Presse Médicale. 2013;42(2):227-30.

22. Huet D, Godbert B, Hermann J, Zordan JM, Chabot F, Andrejak C. Pulmonary infection with Mycobacterium malmoense. Difficulties in diagnosis and treatment. Revue des maladies respiratoires. 2016.

23. Griffith DE, Aksamit T, Brown-Elliott BA, Catanzaro A, Daley C, Gordin F, et al. An official ATS/IDSA statement: diagnosis, treatment, and prevention of nontuberculous mycobacterial diseases. Am J Respir Crit Care Med. 2007;175(4):367-416.

24. Pulmonary disease caused by. M. malmoense in HIV negative patients: 5-yr follow-up of patients receiving standardised treatment. Eur Respir J. 2003;21(3):478-82. 
25. Management of opportunist mycobacterial infections. Joint Tuberculosis Committee Guidelines 1999. Subcommittee of the Joint Tuberculosis Committee of the British Thoracic Society. Thorax. 2000;55(3):210-8.

26. Research Committee of the British Thoracic S. First randomised trial of treatments for pulmonary disease caused by M. avium intracellulare, $M$ malmoense, and $M$. xenopi in HIV negative patients: rifampicin, ethambutol and isoniazid versus rifampicin and ethambutol. Thorax. 2001;56(3):167-72.

27. Buchholz UT, McNeil MM, Keyes LE, Good RC. Mycobacterium malmoense infections in the United States, January 1993 through June 1995. Clin Infect Dis. 1998;27(3):551-8.

28. Jenkins PA, Tsukamura M. Infections with Mycobacterium malmoense in England and Wales. Tubercle. 1979;60(2):71-6.

29. Bollert FG, Watt B, Greening AP, Crompton GK. Non-tuberculous pulmonary infections in Scotland: a cluster in Lothian? Thorax. 1995;50(2):188-90.

30. Grange JM, Yates MD, Pozniak A. Bacteriologically confirmed nontuberculous mycobacterial lymphadenitis in south east England: a recent increase in the number of cases. Arch Dis Child. 1995;72(6):516-7.

31. Moore JE, Kruijshaar ME, Ormerod LP, Drobniewski F, Abubakar I. Increasing reports of non-tuberculous mycobacteria in England, Wales and Northern Ireland, 1995-2006. BMC Public Health. 2010;10:612.

32. Doig C, Muckersie L, Watt B, Forbes KJ. Molecular epidemiology of Mycobacterium malmoense infections in Scotland. J Clin Microbiol. 2002;40(3):1103-5.

33. Rushton SP, Goodfellow M, O'Donnell AG, Magee JG. The epidemiology of atypical mycobacterial diseases in northern England: a space-time clustering and generalized linear modelling approach. Epidemiol Infect. 2007;135(5):765-74

34. Hoefsloot W, Boeree MJ, van Nieuwkoop C, Bernards AT, Savelkoul PH, van Ingen J, et al. No human transmission of Mycobacterium malmoense in a perfect storm setting. Eur Respir J. 2012;40(6):1576-8.

35. Karkamo VSP, Speeti M, Sukura S. Disseminated Mycobacterium malmoense infection in a cat. ResearchGate. 2016.
36. Gunn-Moore DA, McFarland SE, Schock A, Brewer Jl, Crawshaw TR, Clifton-Hadley RS, et al. Mycobacterial disease in a population of 339 cats in Great Britain II Histopathology of 225 cases, and treatment and outcome of 184 cases. J Feline Med Surg. 2011;13(12):945-52.

37. Hughes MS, Ball NW, McCarroll J, Erskine M, Taylor MJ, Pollock JM, et al. Molecular analyses of mycobacteria other than the M. tuberculosis complex isolated from Northern Ireland cattle. Vet Microbiol. 2005;108(1-2):101-12.

38. Ronai Z, Eszterbauer E, Csivincsik A, Guti CF, Dencso L, Janosi S, et al. Detection of wide genetic diversity and several novel strains among non-avium nontuberculous mycobacteria isolated from farmed and wild animals in Hungary. J Appl Microbiol. 2016;121(1):41-54.

39. van Ingen J, Wisselink HJ, van Solt-Smits CB, Boeree MJ, van Soolingen D. Isolation of mycobacteria other than Mycobacterium avium from porcine lymph nodes. Vet Microbiol. 2010;144(1-2):250-3.

40. Asmar S, Sassi M, Phelippeau M, Drancourt M. Inverse correlation between salt tolerance and host-adaptation in mycobacteria. BMC Res Notes. 2016:9:249.

41. Iivanainen EK, Martikainen PJ, Vaananen PK, Katila ML. Environmental factors affecting the occurrence of mycobacteria in brook waters. Appl Environ Microbiol. 1993;59(2):398-404.

42. Katila ML, livanainen E, Torkko P, Kauppinen J, Martikainen P, Vaananen P. Isolation of potentially pathogenic mycobacteria in the Finnish environment. Scand J Infect Dis Suppl. 1995;98:9-11.

43. O'Reilly LM, Daborn CJ. The epidemiology of Mycobacterium bovis infections in animals and man: a review. Tuber Lung Dis. 1995;76(Suppl 1):1-46.

44. Portaels F, Larsson L, Smeets P. Isolation of mycobacteria from healthy person's stools. Int J Lepr. 1988:56(3):465-71.

45. Clarke KA, Fitzgerald SD, Zwick LS, Church SV, Kaneene JB, Wismer AR, et al. Experimental inoculation of meadow voles (Microtus pennsylvaniCus), house mice (Mus musculus), and Norway rats (Rattus norvegicus) with Mycobacterium bovis. J Wildl Dis. 2007;43(3):353-65.

\section{Submit your next manuscript to BioMed Central and we will help you at every step:}

- We accept pre-submission inquiries

- Our selector tool helps you to find the most relevant journal

- We provide round the clock customer support

- Convenient online submission

- Thorough peer review

- Inclusion in PubMed and all major indexing services

- Maximum visibility for your research

Submit your manuscript at www.biomedcentral.com/submit
O Biomed Central 